[Note]

\title{
Selective Epoxidation of Cyclohexene Catalyzed by Lacunary Heteropolyanion Combined with a Ruthenium Complex
}

\author{
Youichi Matsumoto and Makoto Misono* \\ Dept. of Applied Chemistry, Graduate School of Engineering, The University of Tokyo, \\ Hongo, Bunkyo-ku, Tokyo 113
}

(Received September 25, 1996)

\begin{abstract}
The oxidation of cyclohexene produced cyclohexene oxide in much higher yields (90-97\% selectivity at 89-94\% conversion) when a catalytic system combining $\mathrm{RuCl} 2\left(\mathrm{PPh}_{3}\right)_{3}$ with lacunary heteropolyanion, $\mathrm{SiW}_{11} \mathrm{O}_{39^{8-}}$, was used in the presence of dioxygen $(\mathrm{latm})$ and aldehyde at room temperature than when the single components or the combination of the $\mathrm{Ru}$ complex and non-lacunary heteropolyanion, $\mathrm{SiW}_{12} \mathrm{O}_{40^{4-}}$, were used. Lacunary heteropolyanion was stable under the present reaction conditions.
\end{abstract}

\section{Introduction}

Selective catalytic epoxidation has attracted considerable attention. Recently, epoxidation of simple alkenes has been achieved with dioxygen in the presence of aldehydes under mild reaction conditions by using porphyrin or salen complexes of $\mathrm{Co}^{1)}, \mathrm{Mn}^{2)}$, and $\mathrm{Ni}^{3)}$ as well as heteropolyacids4),5). Besides, it has been reported that lacunary heteropolyacids substituted by transition metals catalyzed oxidation of organic substrates with peroxide $^{6)}$. We investigated oxidation of cyclohexene focusing on the effect of combining complex $\left(\mathrm{RuCl}_{2}\left(\mathrm{PPh}_{3}\right)_{3}\right)$ with lacunary heteropolyanions, possible " $\pi$-acceptor ligands" ${ }^{6 a)}$, under co-oxidation of dioxygen and aldehyde? ${ }^{7)}$ and found that epoxides were obtained from the corresponding olefins in high selectivity.

\section{Experimental}

Lacunary heteropolyanions, $\mathrm{K}_{8} \mathrm{SiW}_{11} \mathrm{O}_{39} \cdot n \mathrm{H}_{2} \mathrm{O}$ and $\mathrm{K}_{7} \mathrm{PW}_{11} \mathrm{O}_{39} \cdot n \mathrm{H}_{2} \mathrm{O}$ were prepared as in the literature ${ }^{8)} . \quad \mathrm{K}_{2} \mathrm{TPA}_{6} \mathrm{SiW}_{11} \mathrm{O}_{39}(\mathrm{TPA}=$ tetra- $n$-pentylammonium) (1) was prepared by vigorously mixing $5 \mathrm{~g}$ of $\mathrm{K}_{8} \mathrm{SiW}_{11} \mathrm{O}_{39} \cdot n \mathrm{H}_{2} \mathrm{O}$ dissolved in 100 $\mathrm{ml}$ of water and $3.24 \mathrm{~g}$ of $\left(\mathrm{C}_{5} \mathrm{H}_{11}\right)_{4} \mathrm{NBr}$ in $30 \mathrm{ml}$ of water. The resultant precipitate was filtered off and washed with water and ether, and then dried in vacuo. $\mathrm{K}_{2}$ (TBA) $)_{5} \mathrm{PW}_{11} \mathrm{O}_{39}$ (TBA=tetra- $n$-butylammonium) and $\mathrm{K}_{2}(\mathrm{TPA})_{6} \mathrm{SiW}_{11} \mathrm{O}_{39}$ were also prepared similarly. A typical procedure for oxidation reaction was as follows. $\mathrm{K}_{2} \mathrm{TPA}_{6} \mathrm{SiW}_{11} \mathrm{O}_{39}$

* To whom correspondence should be addressed.
$(0.025 \mathrm{mmol})$ and $\mathrm{CH}_{2} \mathrm{Cl}_{2}(6 \mathrm{ml})$ were introduced into a $30 \mathrm{ml}$, two-necked, round-bottomed flask equipped with a magnetic stirrer under a dry argon atmosphere. After several freeze-pump-thaw cycles $\mathrm{RuCl}_{2}\left(\mathrm{PPh}_{3}\right)_{3}(2)(0.025 \mathrm{mmol})$ was added to the solution. After stirring the mixture for $c a$. $20 \mathrm{~min}, 1 \mathrm{~atm}$ of $\mathrm{O}_{2}$ gas was introduced into the system, and then olefin ( $1 \mathrm{mmol})$ and aldehyde $(2.5 \mathrm{mmol})$ were added dropwise to the mixture. The products were analyzed by a gas chromatograph (Shimadzu GC-8A) equipped with a Gaskuropak $55(4 \mathrm{~m})$ and a thermal conductivity detector.

\section{Results and Discussion}

Typical results under various reaction conditions are collected in Table 1. Products from cyclohexene contained, besides cyclohexene oxide, cyclohexenone and cyclohexenol but not cyclohexanol, cyclohexanone, adipic acid, and 1,2cyclohexandiol. In the case of the combination of aldehyde, ruthenium complex (2), and lacunary heteropolyanion (run 1), the epoxide was obtained in over $90 \%$ selectivity. The yield after $8-12 \mathrm{~h}$ was $80-91 \%$, but a quite high yield $(77 \%$, run 1') was obtained within $2 \mathrm{~h}$. The performance was much better in $\mathrm{CH}_{2} \mathrm{Cl}_{2}$ than in $\mathrm{CH}_{3} \mathrm{CN}$ (runs 1 and 2). In the absence of aldehyde the epoxide was not formed (run 6). Although the reaction proceeded without a catalyst (run 5) or with the ruthenium complex (2) in the absence of heteropolyanion (run 7), the yield of epoxide was much higher when the complex was combined with lacunary heteropolyanion (run 1). In the case of lacunary 
Table 1 Oxidation of Cyclohexene in the Presence of Oxygen and Aldehydea)

\begin{tabular}{|c|c|c|c|c|c|c|}
\hline Run & Catalyst & Time $[\mathrm{h}]$ & Solv. & Conv. [\%] & Yield [\%]卢) & Select. [\%] $]^{\mathrm{c}}$ \\
\hline 1 & $2+\mathrm{QSiW}_{11} \mathrm{O}_{39}$ & 8-12 & $\mathrm{CH}_{2} \mathrm{Cl}_{2}$ & $89-94$ & $80-91$ & $90-97$ \\
\hline l', & $2+\mathrm{QSiW}_{11} \mathrm{O}_{39}$ & 2 & $\mathrm{CH}_{2} \mathrm{Cl}_{2}$ & 82 & 77 & 93 \\
\hline 2 & $2+\widetilde{Q S i W}_{11} \mathrm{O}_{39}$ & 19 & $\mathrm{CH}_{3} \mathrm{CN}$ & 95 & 34 & 36 \\
\hline 3 & $2+Q^{\prime} \mathrm{SiW}_{12} \mathrm{O}_{40}$ & 12 & $\mathrm{CH}_{2} \mathrm{Cl}_{2}$ & 96 & 58 & 60 \\
\hline 4 & $\mathrm{QSiW}_{11} \mathrm{O}_{39}$ & 21 & $\mathrm{CH}_{2} \mathrm{Cl}_{2}$ & 39 & 18 & 47 \\
\hline 5 & No catalyst & 24 & $\mathrm{CH}_{2} \mathrm{Cl}_{2}$ & 28 & 17 & 61 \\
\hline 6 & $2+Q^{\prime \prime} \mathrm{SiW}_{11} \mathrm{O}_{39^{\mathrm{d}}}$ & 24 & $\mathrm{CH}_{3} \mathrm{CN}$ & 19 & 0 & 0 \\
\hline \multirow[t]{4}{*}{7} & $\mathrm{RuCl}_{2}\left(\mathrm{PPh}_{3}\right)_{3}$ & 10 & $\mathrm{CH}_{2} \mathrm{Cl}_{2}$ & 97 & 64 & 65 \\
\hline & $\mathrm{Ni}(\mathrm{dmp})_{2}^{\mathrm{e})}$ & 1 & $\mathrm{CH}_{3} \mathrm{CN}$ & 31 & 20 & 65 \\
\hline & $\mathrm{PW}_{11} \mathrm{CoO}_{39^{5-e)}}$ & 1 & $\mathrm{CH}_{3} \mathrm{CN}$ & 41 & 33 & 80 \\
\hline & $\left.\left(\mathrm{NH}_{4}\right)_{5} \mathrm{H}_{4} \mathrm{PV}_{6} \mathrm{Mo}_{6} \mathrm{f}\right)$ & 4 & $\mathrm{CH}_{2} \mathrm{Cl}_{2}$ & 83 & 78 & 94 \\
\hline
\end{tabular}

a) Reaction conditions; catalyst $(0.025 \mathrm{mmol})$, cyclohexene ( $1 \mathrm{mmol})$, aldehyde $(2.5 \mathrm{mmol})$ temperature (room temp.) and reaction time $(10-24 \mathrm{~h})$. b) By GC analysis. c) Selectivity to cyclohexene oxide. d) Without aldehyde. e) Ref. 4. dmp=l,3-bis $(p-$ methoxyphenyl-1,3-propanedionato). f) Ref. 5. 2: $\mathrm{RuCl}_{2}\left(\mathrm{PPh}_{3}\right)_{3}, \mathrm{Q}: \mathrm{K}_{2}(\mathrm{TBA})_{6}, \mathrm{Q}^{\prime}: \mathrm{K}_{2}(\mathrm{TPA})_{6}, \mathrm{Q}^{\prime \prime}: \mathrm{K}_{2}(\mathrm{TBA})_{5}$.

heteropolyanion without the ruthenium complex (2) (run 4), the selectivity was lower than in the case without a catalyst (run 5). Combination with the Keggin-type heteropolyanion (run 3), instead of lacunary anions, showed performance similar to that of he Ru-complex alone (run 7). Therefore, the high selectivity at high conversion levels was brought about by a synergistic effect of lacunary heteropolyanion (1) and Ru-complex (2). The high yields observed in run 1 is remarkable as compared with those in the literature (last three lines in Table 1) $)^{4), 5}$.

The stability of polyanions and the possible complexation were examined by IR and ${ }^{31} \mathrm{P}-\mathrm{NMR}$. The IR spectrum of 1 in $\mathrm{CH}_{2} \mathrm{Cl}_{2}$ showed absorption bands at $1014 \mathrm{~cm}^{-1}$ for terminal $\mathrm{W}=\mathrm{O}$, $963 \mathrm{~cm}^{-1}$ for $\mathrm{Si}-\mathrm{O}$, and 902 and $793 \mathrm{~cm}^{-1}$ for the two types of bridging $\mathrm{W}-\mathrm{O}-\mathrm{W}$ as in the literature ${ }^{6 \mathrm{~b})}$. Since, these IR bands little changed after run 1 , the framework of heteropolyanion structure remained essentially intact during the in-situ preparation and reaction of run 1 . The ${ }^{31} \mathrm{P}-\mathrm{NMR}$ signal for the heteroatom of $\mathrm{K}_{2} \mathrm{TBA}_{5} \mathrm{PW}_{11} \mathrm{O}_{39}$ shifted downfield by $0.2 \mathrm{ppm}(-12.16$ to -11.94 ppm with reference to tri- $n$-butylphosphate) and the linewidth increased slightly by the addition of Ru-complex (2). The changes were small but still greater than those in the case of nonlacunary $\mathrm{TBA}_{3} \mathrm{PW}_{12} \mathrm{O}_{40}(0.06 \mathrm{ppm}$, from -14.68 to -14.62 $\mathrm{ppm}$ ). If one considers the shift to be usually very small6a),9), the present observation suggests the presence of interaction between the lacunary heteropolyanion and the Ru-complex.

Now, the reaction mechanism will be briefly discussed. The catalytic system for epoxidation may be classified into two major types. One is the oxygen transfer processes involving oxometal (or peroxometal) complexes as the active oxidants ${ }^{10}$. The other is the radical chain reactions initiated by metal complexes ${ }^{11)}$. In the latter case, the role of

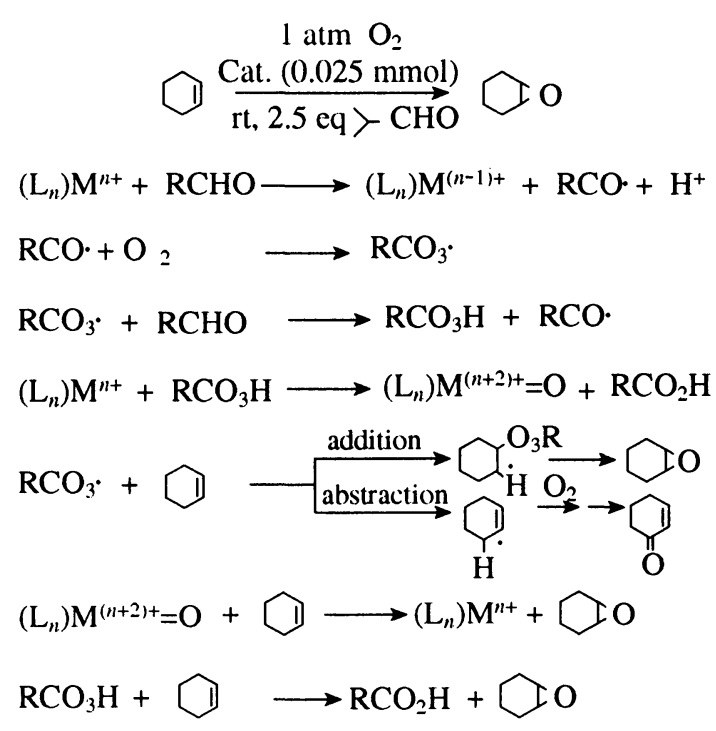

aldehyde usually is to generate an acyl radical by reacting with a metal complex (Eq. (2)). Three possible active species may be derived from the acyl radical: acylperoxy radical (Eq. $(3))^{11)}$, peracid (Eq. (4) $)^{12)}$, and oxometal complex (Eq. $\left.(5)\right)^{11), 13)}$. The relative importance of these changes in the reaction depends on the reaction systems and conditions ${ }^{13), 14)}$. Murahashi et al. ${ }^{15)}$ have indicated that oxometal species is the more important species for the reaction of aldehyde and dioxygen with $\mathrm{Ru}$ complex (2). Nam et al. have recently reported that in the case of oxidation by dioxygen plus aldehyde in the presence of $\mathrm{Fe}, \mathrm{Co}, \mathrm{Ni}, \mathrm{Cr}$, and $\mathrm{Mn}$ complexes, the principal role of metal complexes is to aid the formation of acyl radical and that the active species are acylperoxy radicals (Eq. (6a)) rather than peracids (Eq. (8)) or oxometal complexes (Eq. (7)) ${ }^{13)}$.

We carried out oxidation of cis-stilbene with the present catalytic system and observed nonstereospecific formation of the corresponding 
epoxides. The trans/cis ratio of epoxide was 79/ 21 , the isolated yield after $4 \mathrm{~h}$ at room temperature was $65 \%$. This indicates that the epoxidation proceeded mainly via a radical reaction (probably via acyl peroxy radical) rather than via peracid as discussed by Nam et al. ${ }^{13)}$. The oxidation of styrene carried out under the our present reaction conditions formed benzaldehyde and styrene epoxide (aldehyde/epoxide=77/23). The formation of benzaldehyde indicates the radical path ${ }^{16)}$, but the formation of epoxide shows that there is a path via peracid (Eq. (8)) $)^{17)}$ or oxoruthenium (Eq. (7)).

In summary, by using a combination of $\mathrm{RuCl}_{2}\left(\mathrm{PPh}_{3}\right)_{3}$ and lacunary Keggin-type heteropolyanions as catalysts in $\mathrm{CH}_{2} \mathrm{Cl}_{2}$, cyclohexene was oxidized to epoxides with high selectivity and yield in the presence of dioxygen and aldehyde at ambient temperature; for example, cyclohexene was epoxidized with $90-97 \%$ selectivity.

\section{Acknowledgments}

This work was financially supported in part by a Grant-Aid for Scientific from the Ministry of Education, Science, Sports and Culture of Japan.

\section{References}

1) Mastrorilli, P., Nobile, C. F., J. Mol. Cat., 94, 19 (1994).

2) Pietikainen, P., Tetrahedron Lett., 36, 319 (1995).
3) Yamada, T., Takai, T., Rhode, O., Mukaiyama, T., Bull. Chem. Soc. Jpn., 64, 2109 (1991).

4) Mizuno, N., Hirose, T., Tateisi, M., Iwamoto, M., Chem. Lett., 1839 (1993).

5) Hamamoto, M., Nakayama, K., Nishiyama, Y., Ishii, Y., J. Org. Chem., 58, 6421 (1993).

6) a) Rong, C., Pope, M. T., J. Am. Chem. Soc., 114, 2932 (1992). b) Neumann, R., Abu-Gnim, C., J. Am. Chem. Soc., 112, 6025 (1990).

7) Tsuchiya, F., Ikawa, T., Can. J. Chem., 47, 3191 (1969).

8) Tézé, A., Hervé, G., J. Inorg. Nucl. Chem., 29, 919 (1977).

9) Massart, R., Contart, R., Fruchart, J. M., Ciabrini, J. R., Fournier, M., Inorg. Chem., 16, 2916 (1977).

10) Mimoun, H., in Wilkinson, G., Gillard, R. D., McCleverty, J. A., (Eds.), "Comprehensive Coordination Chemistry," Vol. 6, Pergamon, New York (1987), p. 317; Sheldon, R. A., (Ed.), "Metallporphyrins in Catalytic Oxidation," Marcel Dekker, New York (1994); Jorgensen, K. A., Chem. Rev., 89, 431 (1989).

11) Sheldon, R. A., Kochi, J. K., "Metal-Catalyzed Oxidations of Organic Compounds," Academic Press, New York (1981).

12) Swern, D., “Organic Peroxides,” Vol. 2, John Wiley and Sons, New York (1972), Chap. 5.

13) Nam, W., Kim, H. J., Kim, S. H., Ho, R. Y. N., Valentine, J. S., Inorg. Chem., 35, 1045 (1996).

14) Barf, G. A., Sheldon, R. A., J. Mol. Catal., 102, 23 (1995).

15) Murahashi, S.-I., Oda, Y., Naota, T., J. Am. Chem. Soc., 114, 7913 (1992).

16) Lyons, J. E., Turner, J. O., Tetrahedron Lett., 29, 2903 (1972).

17) Kaneda, K., Haruna, S., Imanaka, T., Hamamoto, M., Nishiyama, Y., Ishii, Y., Tetrahedron Lett., 36, 6827 (1992).

要 旨

欠損型ヘテロポリアニオンとルテニウム化合物の複合触媒系によるシクロヘキセンの選択的エポキシ化

\author{
松本 陽一, 御園生 誠
}

東京大学大学院工学系研究科応用化学専攻, 113 東京都文京区本郷 7-3-1

\footnotetext{
欠損型ヘテロポリアニオン $\left(\mathrm{SiW}_{11} \mathrm{O}_{39}{ }^{8-}\right)$ とルテニウムホス

錯体の複合系に比較し，高い収率（転化率 $89 \sim 94 \%$, 選択率 フィン錯体 $\left(\mathrm{RuCl}_{2}\left(\mathrm{PPh}_{3}\right)_{3}\right)$ の複合系を触媒とすると, 室温, 90〜97\%）でシクロヘキセンがエポキシ化することを見い出し

酸素 $(1 \mathrm{~atm})$, イソブチルアルデヒド存在下において, 各単独 た。欠損型へテロポリアニオンは反応前後で安定である。
}

系ならびに非欠損型ヘテロポリアニオン $\left(\mathrm{SiW}_{12} \mathrm{O}_{40}{ }^{4-}\right)$ と $\mathrm{Ru}$

\title{
Keywords
}

Epoxidation, Lacunary heteropolyanion, Ruthenium catalyst, Selectivity, Dioxygen, Aldehyde 